\title{
Effects of Rice Straw Management on Sclerotium oryzae Inoculum, Stem Rot Severity, and Yield of Rice in California
}

\author{
N. A. Cintas and R. K. Webster, Department of Plant Pathology, University of California, Davis 95616
}

\begin{abstract}
Cintas, N. A., and Webster, R. K. 2001. Effects of rice straw management on Sclerotium oryzae inoculum, stem rot severity, and yield of rice in California. Plant Dis. 85:1140-1144.

Under continuous rice cropping, open field burning has been the primary means of rice residue disposal and of minimizing the carryover inoculum of Sclerotium oryzae, the cause of stem rot of rice. The phase down of open field burning in California has necessitated the development of alternatives to burning. In 1993, a continuous-year experiment was initiated in Colusa County to evaluate the effects of alternative residue management strategies on overwintering sclerotia of S. oryzae, stem rot incidence and severity, and yield. Treatments were arranged in a split-plot design with winter flooding and winter nonflooding as the main plots, and fall incorporation of the straw residue, rolling of the straw to enhance soil contact, baling and removal of residue, and fall burning as the subplots. $S$. oryzae inoculum and disease severity were significantly lower and yield was significantly higher in 5 out of 6 years in the winter-flooded main plots compared with the winter nonflooded plots. Over the duration of the trial, S. oryzae inoculum was consistently lower in burn subplots when compared with all other subplots. No consistent differences in disease incidence and severity or yield occurred in the subplots, although average yield over the 6 years was highest in burn subplots when compared with all other subplots. The results suggest that winter flooding is the best alternative to burning for stem rot management.
\end{abstract}

Additional keywords: cultural control, Magnaporthe salvinii, Oryza sativa

Stem rot, caused by the fungus Sclerotium oryzae Cattaneo, is a serious disease of rice worldwide $(18,24)$, including in California $(13,15,31,32)$. The sclerotia produced by the fungus serve as primary inoculum by floating on the water and infecting rice stems at the waterline $(2,10,24,32)$. Sclerotia form abundantly in infected tissues as the rice plant nears maturity and continue to form in crop debris (32).

The most effective means of managing stem rot in California has been by burning infested rice residue and stubble that is left in the field after harvest to minimize overwintering inoculum. Legislation has required a reduction in agricultural burning in the Sacramento Valley Air Basin (3) so that, by the year 2000, permitted burns will be allowed on only $25 \%$ of rice acreage

Corresponding author: N. A. Cintas

E-mail: cintas@salinis.ars.usda.gov

Current address of N. A. Cintas: USDA-ARS, PWA; 1636 E. Alisal St.; Salinas, CA 93905.

This research was primarily funded by the Rice Research Board of California and in part by Ducks Unlimited.

Accepted for publication 22 June 2001.

Publication no. D-2001-0820-03R

(C) 2001 The American Phytopathological Society planted. A recent stay on the mandated phasedown was passed by the state legislature to allow more time to find alternatives to burning rice straw for disease and residue management (4). With the imminent loss of most residue and stubble burning, alternative management strategies will be needed in the future.

Likely alternatives to burning include rolling, incorporation, and baling and removing of residue, with and without winter flooding. Rolling the residue increases its contact with the soil, which enhances its access to microorganisms for decomposition. Incorporation increases contact between residue and soil even more, which in turn increases decomposition (22). Baling and removal of rice straw is intended to remove residue, inoculum, and substrate for further inoculum production. Winter flooding is attractive as a means of enhancing decomposition and providing habitat for waterfowl in rice paddies during the winter.

Previous field trials have shown that maintaining or fluctuating soil moisture results in a reduction of sclerotial viability (12). Straw incorporation by means of moldboard plowing has been shown to reduce the total number of sclerotia by burying them and rendering them unavailable to float to the surface of flooded paddies in the spring and cause infection as the rice emerges from the flood water $(10,30)$.
Straw incorporation, when compared with no-tillage, also reduces sclerotial viability (10), perhaps due to dislodging sclerotia from the residue, increasing their contact with the soil, and enhanced microbial activity. S. oryzae sclerotia which are in contact with soil have a half-life of 1.9 years (1). Baling and removal of rice straw has been reported to be nearly as effective as burning for reducing overwintering inoculum $(2,29)$. In preliminary trials, winter flooding decreased the number of sclerotia recovered from soil when compared with winter nonflooding.

The objective of this research was to determine potential alternatives to open field burning of residue (with or without winter flooding) under continuous rice cropping.

\section{MATERIALS AND METHODS}

Field design. A field study was established to determine and compare the effects of alternative treatments to burning rice straw residue on $S$. oryzae inoculum levels, stem rot incidence and severity, and yield. A 74-acre field trial in Colusa County was established in the fall of 1993, followed by the first crop of rice grown in 1994. The trial was arranged in a split-plot design. The main plots were winter flooding and winter nonflooding, with subplots of fall burning, fall baling and removing, fall incorporation of rice residue, or fall rolling to enhance soil contact (Fig. 1). Subplots were 1.9 acres. Each subplot practice was completed in the fall soon after harvest. All straw management treatments were completed prior to winter flooding except for the flood and roll subplot, which was cage rolled with 3 to 5 in. of standing water. Winter-flooded main plots were flooded in late October or early November and drained in late February or early March of each year. Each subplot was established with a separate irrigation system to prevent movement of inoculum between subplots. Treatments were replicated four times and cv. M-202 was planted each season. All other cultural practices employed at the site were typical of standard rice production systems used in California, including water seeding (8).

Soil sampling. Soil samples were collected from the prepared seedbeds in the spring just prior to flooding. The soil type was Willows Clay Moderate Alkaline (9). Due to the large size of the subplots, each 
subplot was split into three sections for sampling. Within each section, a "W" pattern was walked. Along this "W" 10 to 12 samples were taken with a garden trowel from the upper $2 \mathrm{in}$. of the seedbed, where the inoculum that causes disease lies $(26,27)$. Soil samples collected along the "W" were combined as a composite sample and, when necessary, air dried before processing. All soil samples were ground in a soil grinder (Iler Improved; The Fen Machine Co., Cleveland, $\mathrm{OH}$ ) that was adjusted for a minimum clearance of 2 $\mathrm{mm}$. Sclerotia from the soil samples were then retrieved using the procedure developed by Krause and Webster (14) with the following modifications: (i) the filtrate in the Buchner funnel was surface disinfestated with a solution of $8 \mathrm{ml}$ of commercial bleach $(5.25 \%$ sodium hypochlorite) and $92 \mathrm{ml}$ of water (followed by three rinses with deionized water), and (ii) sclerotia were placed on water agar plates amended with $100 \mathrm{ppm}$ chlorotetracycline.

Plant sampling. Plant samples were collected annually from 1994 to 1999 . Samples were collected near rice maturity, when the field was being drained for harvest. Tillers were cut below the water line (and above the roots) from approximately the same areas where the soil samples were collected. In all, 10 to 12 samples of at least 10 tillers were collected along a "W" path within each subplot section. For each section of the subplot, over 100 tillers were collected for disease evaluation. Plant samples were rated for disease by the method developed by Krause and Webster (15) (i.e., healthy and infected tillers were divided into five categories based on the amount of disease: 1 = healthy, no symptoms; 2 = slightly infected with symptoms and sclerotia on the outer leaf sheaths only; $3=$ mildly infected with discoloration of the inner leaf sheaths, culm green and healthy; 4 = moderately infected, slight to mild discoloration of the culm, interior of the culm healthy; and $5=$ severely infected, culms infected internally, either collapsed or not). The disease index is then calculated as follows: disease severity or disease index $=\left[1\left(\mathrm{H}^{\mathrm{n}}\right)+2\left(\mathrm{~L}^{\mathrm{n}}\right)+3\left(\mathrm{M}^{\mathrm{n}}\right)+\right.$ $\left.4\left(\mathrm{M}^{* \mathrm{n}}\right)+5\left(\mathrm{~S}^{\mathrm{n}}\right)\right] /$ total number of tillers examined, where $\mathrm{H}^{\mathrm{n}}=$ number of healthy tillers, $\mathrm{L}^{\mathrm{n}}=$ number of lightly infected tillers, $\mathbf{M}^{\mathrm{n}}=$ number of mildly infected tillers, $\mathrm{M}^{* \mathrm{n}}=$ number of moderately infected tillers, and $S^{n}=$ number of severely infected tillers. A rating of 1 indicates a sample of all healthy tillers, and a rating of 5 indicates a sample with all severely infected tillers.

Data for each subplot were averaged before proceeding with analyses.

Panicle weights. To determine the relationship between the disease severity rating and yield, over 10,000 panicles were collected in both 1996 and 1997. Individual tillers were rated for disease severity and weight of the panicle from each tiller was determined. After tillers were rated for disease severity, all panicles within each severity class were clipped from the stems and dried individually in a drying oven at $65^{\circ} \mathrm{C}$ until no weight loss from day to day was measurable. Panicles then were weighed to determine their dry weight.

Yield determination. Yields of paddy rice, at $14 \%$ moisture, were determined for each plot each year. Each season, the majority of each subplot was harvested (minus microplots within). In 1997, however, the yield was determined from a section $570 \mathrm{ft}$ long by $32 \mathrm{ft}$ wide (twice the width of the harvester header) harvested in two strips through the center of each subplot.

Statistical analysis. Split-plot analysis of variance was performed using SAS (SAS Institute Inc., Cary, NC) to determine differences in sclerotial levels, disease levels, and yield between main plots and subplots and the interactions between main and subplot treatments. When significant differences in means were found with analysis of variance (ANOVA), least significant difference analysis was used for mean separation. Correlation and regression analyses were performed using SAS REG and CORR procedures to determine the relationship between disease severity versus yield.

For the panicle weight per tiller data sets, correlation and regression analyses were also performed using SAS REG and CORR procedures to determine the relationship between disease severity and yield.

\section{RESULTS}

Inoculum levels. In each year, except 1994, ANOVA revealed significant differ-

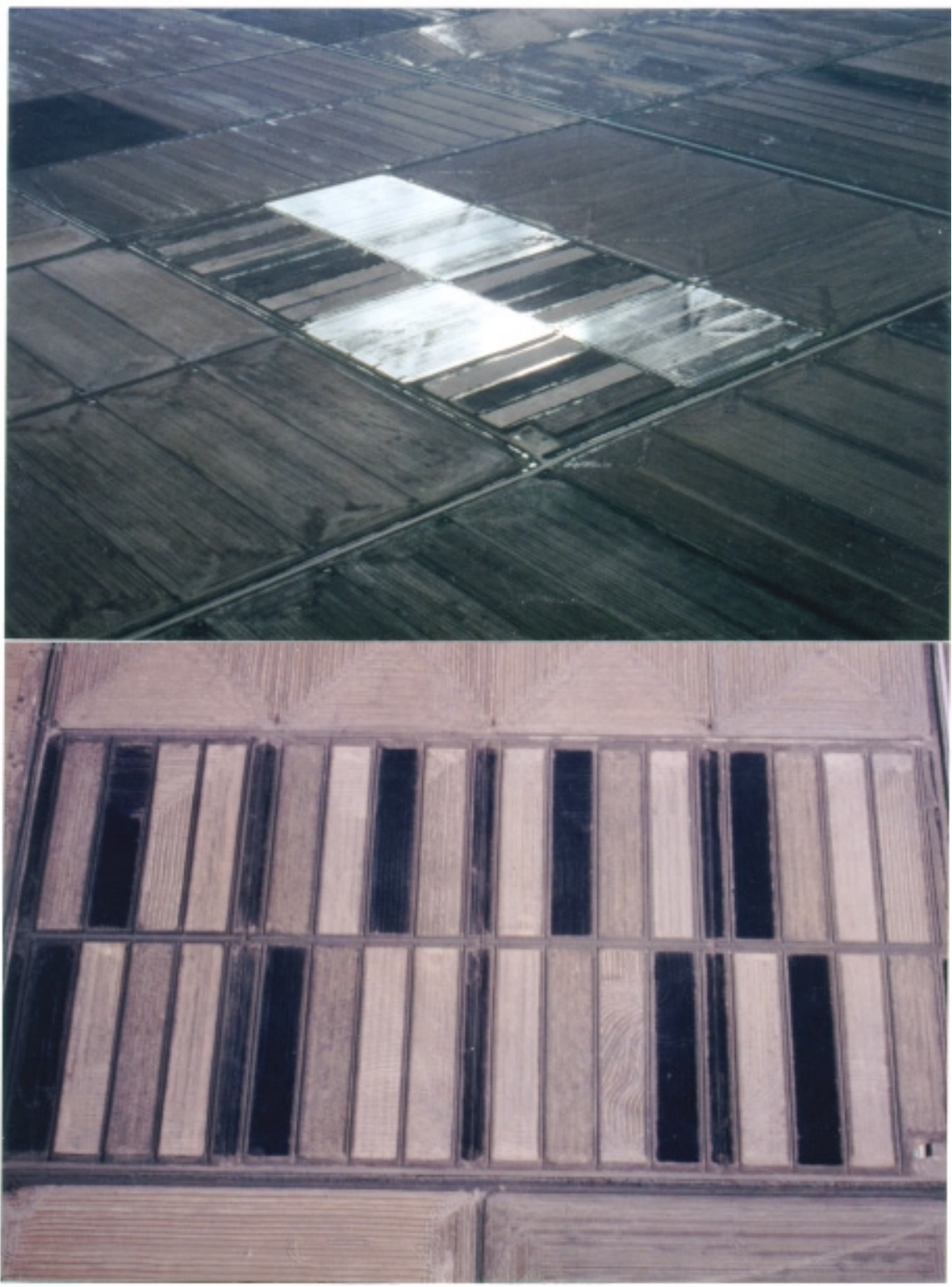

Fig. 1. Top: aerial view of winter-flooded and winter nonflooded main plots at the 74-acre Colusa County site. Bottom: aerial view of the baled, incorporated, rolled, and (the most obvious) darkened, burned subplots. Each subplot had a separate irrigation system so that no passage of inoculum occurred between subplots. 
ences in means between the main plot treatments. Mean separation analysis indicated that, after the initial year of the trial, there were significantly fewer viable sclerotia recovered per gram of soil each year in the winter-flooded plots compared with the winter-nonflooded plots (Table 1). ANOVA revealed significant differences in means each year between the main plot treatments. Mean separation analysis indicated that significantly fewer viable sclerotia were recovered from the burned subplots each year of the trial compared with all other subplots (Table 1). Significantly greater viable sclerotia were recovered from the rolled subplots each year compared with all other subplots (Table 1).

After the initial year of the trial, interactions between residue management and winter flooding management were significant in regards to the number of viable sclerotia per gram of soil $(P \leq 0.05)$ (Table 1).

Disease severity. In 5 out of 6 years, there were significant differences in disease severity between main plot treat- ments; mean separation revealed a significant reduction in disease severity in the winter-flooded plots compared with the winter-nonflooded plots (Table 2). There were significant differences in stem rot severity between straw management subplots in 5 out of 6 years determined by ANOVA, but mean separation did not reveal any consistent differences in severity between subplots treatments (Table 2). Interactions between residue management and winter flooding management and their effect on disease severity were significant only in 1996 with a $\operatorname{Pr}>F$ value of 0.0372 $(P \leq 0.05)$

Yield. In every year except 1997, significant differences in yield between main plot treatments were determined by ANOVA. Mean separation analysis revealed that yield was significantly higher in the winter-flooded plots compared with the winter-nonflooded plots (Table 2). There were significant differences in yield between straw management subplots over the 6 years of the field trial, as determined by ANOVA, but mean separation revealed no consistency to these differences (Table 2 ). Burn subplot yields were highest in 3 of the 6 years and averaged highest overall for the duration of the trial. Interactions between residue management and winter flooding management and their effect on yield were not significant.

Disease severity versus individual panicle weight. The Pearson correlation coefficient between stem rot severity and panicle weight in 1997 was determined to be $-0.60(P=0.0001, n=135)$. As stem rot severity increased from healthy through various ratings to severe, there was a significant reduction in total weight of the panicles with a significant negative correlation. The relationship between disease severity levels measured and reduction in yield in 1997 is shown in Figure 2. The severity-yield relationship was well described by a linear regression model as indicated by a highly significant coefficient of determination $\left(r^{2}\right)$ of $0.36(P=0.0001, n$ =135).

Disease severity versus yield. The Pearson correlation coefficients between

Table 1. Effects of winter flooding and various residue management treatments on Sclerotium oryzae inoculum

\begin{tabular}{|c|c|c|c|c|c|c|c|}
\hline \multirow[b]{2}{*}{ Plots ${ }^{b}$} & \multicolumn{7}{|c|}{ Viable sclerotia per gram soil $^{\mathrm{a}}$} \\
\hline & 1994 & 1995 & 1996 & 1997 & 1998 & 1999 & Mean \\
\hline \multicolumn{8}{|l|}{ Main plots } \\
\hline Flood & 1.35 & 0.98 & 0.94 & 0.78 & 0.77 & 0.51 & 0.88 \\
\hline Non flood & 1.52 & 1.68 & 1.51 & 2.05 & 2.21 & 1.58 & 1.76 \\
\hline LSD & NS & 0.2999 & 0.2139 & 0.4571 & 0.3052 & 0.2935 & $\ldots$ \\
\hline \multicolumn{8}{|l|}{ Subplots } \\
\hline Burn & 1.03 & 0.63 & 0.62 & 0.52 & 0.60 & 0.33 & 0.62 \\
\hline Incorporate & 1.48 & 1.15 & 1.33 & 1.36 & 1.42 & 0.93 & 1.27 \\
\hline Bale & 1.30 & 1.20 & 1.23 & 1.35 & 1.68 & 0.96 & 1.12 \\
\hline Roll & 1.91 & 1.86 & 1.73 & 2.43 & 2.26 & 1.97 & 2.02 \\
\hline LSD & 0.4384 & 0.4241 & 0.3024 & 0.6465 & 0.4317 & 0.415 & $\ldots$ \\
\hline Main-subplot & 0.0761 & 0.2136 & $0.0024^{*}$ & $0.0278^{*}$ & $0.0027^{*}$ & $0.0016^{*}$ & $\cdots$ \\
\hline
\end{tabular}

a Soil samples were collected from prepared seedbeds; NS $=$ not significant.

${ }^{\mathrm{b}} \mathrm{LSD}=$ least significant difference at $P \leq 0.05 .{ }^{*}=$ significant at $P \leq 0.05, \operatorname{Pr}>F$ values for main-subplot interaction.

Table 2. Effects of winter flooding and various residue management treatments on stem rot disease severity and yield of rice at the Colusa site

\begin{tabular}{|c|c|c|c|c|c|c|c|}
\hline Plots $^{\mathbf{a}}$ & 1994 & 1995 & 1996 & 1997 & 1998 & $1999^{b}$ & Mean \\
\hline \multicolumn{8}{|c|}{ Stem rot severity } \\
\hline \multicolumn{8}{|l|}{ Main plots } \\
\hline Flood & 2.61 & 3.18 & 3.66 & 2.58 & 3.06 & 3.02 & 3.01 \\
\hline Nonflood & 3.02 & 3.72 & 4.14 & 2.67 & 3.31 & 3.37 & 3.37 \\
\hline LSD & 0.19 & 0.28 & 0.17 & 0.15 & 0.19 & 0.21 & $\ldots$ \\
\hline \multicolumn{8}{|l|}{ Subplots } \\
\hline Burn & 2.77 & 3.26 & 3.77 & 2.60 & 2.90 & 2.87 & 3.02 \\
\hline Incorporate & 2.67 & 3.39 & 3.73 & 2.62 & 3.06 & 3.21 & 3.11 \\
\hline Bale & 3.04 & 3.65 & 4.08 & 2.69 & 3.39 & 3.38 & 3.37 \\
\hline Roll & 2.79 & 3.49 & 4.00 & 2.60 & 3.37 & 3.21 & 3.24 \\
\hline LSD & 0.27 & 0.39 & 0.25 & 0.21 & 0.17 & NS & $\ldots$ \\
\hline \multicolumn{8}{|c|}{ Yield pounds $\backslash$ acre at $14 \%$} \\
\hline \multicolumn{8}{|l|}{ Main plots } \\
\hline Flood & 8,300 & 9,084 & 9,250 & 10,366 & 7,825 & 9,214 & 9,006 \\
\hline Nonflood & 7,846 & 8,076 & 8,927 & 10,331 & 7,287 & 8,823 & 8,548 \\
\hline LSD & 421 & 413 & 236 & 272 & 243 & 283 & $\ldots$ \\
\hline \multicolumn{8}{|l|}{ Subplots } \\
\hline Burn & 8,882 & 8,561 & 9,240 & 10,496 & 7,665 & 9,285 & 9,021 \\
\hline Incorporate & 7,820 & 8,774 & 8,766 & 10,072 & 7,721 & 8,512 & 8,610 \\
\hline Bale & 8,167 & 8,255 & 9,137 & 10,365 & 7,365 & 9,149 & 8,739 \\
\hline Roll & 7,424 & 8,730 & 9,192 & 10,462 & 7,472 & 9,114 & 8,732 \\
\hline LSD & 596 & 584 & 334 & 385 & 224 & 429 & $\ldots$ \\
\hline
\end{tabular}

a Stem rot severity is based on a scale of 1 to 5 , where $1=$ healthy and $5=$ severely infected. LSD $=$ least significant difference.

b NA = not applicable. 
stem rot severity and harvested yields were years, the relationship between severity and yield was strongly inversely proportional, with 2 of the 3 years having highly significant negative correlation coefficients (Table 3).

\section{DISCUSSION}

Fall incorporation followed by winter flooding resulted in a decrease in stem rot severity as well as an increase in yield. These results suggest that fall straw management followed by winter flooding is a viable management strategy for stem rot of rice to replace open field burning.

The average number of viable sclerotia per gram of soil in the first year of the trial was 1.43. Burning reduced the number of viable sclerotia per gram of soil to 0.33 by 1999. Past reports have shown burning maintains or decreases levels of viable sclerotia per gram of soil, while unburned plots resulted in increasing numbers of viable sclerotia $(30,32)$. Significant interactions between main plot and subplot treatments for the number of viable sclerotia suggest that winter flooding of plots may have influenced inoculum levels differently depending on the straw management treatment. Specifically, burning rice residue effectively reduced inoculum whether the plots were flooded in the winter or not, but all other straw management treatments resulted in significantly lower inoculum levels in plots that had also been flooded in the winter (6).

In past studies of stem rot in California, inoculum levels and disease severities varied. At a Butte County rice field studied in the late 1970s, inoculum levels ranging from 0.24 to 1.15 viable sclerotia per gram of soil resulted in stem rot severities of 1.59 to 2.45 (31). At a Sutter County site determined in 1994 to 1997 . In 3 of 4

sampled in the early 1990s, similar levels of 0.26 viable sclerotia per gram of soil resulted in stem rot severities averaging about 2.7 (26). The cultivar grown in this study, M-202, has a yield that is less affected by stem rot than many commercial cultivars grown in the past. The sclerotial density at the Colusa site exceeded 0.6 viable sclerotia per gram. The resulting severities were, on average, closer to a rating of 3 . When looking for rice lines resistant to stem rot, the more resistant cultivars not only showed a reduction in stem rot severity, but also in sclerotial production (17). Sites with different sclerotial densities may have similar levels of stem rot severities due to the tolerance of the cultivar grown.

According to Kiem and Webster, alternate wetting and drying of $S$. oryzae sclerotia in rice soils reduced sclerotial viability (12), which supports the results of our study where winter flooding reduced the number of viable sclerotia per gram of soil from 1.35, in the initial year of the trial, to 0.51 by 1999 . It is possible that the total number of sclerotia recovered was lower in the winter-flooded treatments because the high soil water content increased the rate of decomposition of the sclerotia. The rate of rice straw decomposition increased when the soil was moderately moist $(60 \%$ moisture) compared with soils with low or high moisture, 30 or $150 \%$, respectively $(16,19)$. As temperature increased, the rate of rice straw decomposition also increased $(16,20)$. Thus, it is not surprising that, as temperature and moisture increased, rice straw decomposition also increased $(16,21)$. Winter flooding may aid in the decomposition of sclerotia because the winter-flooded paddies are usually wet longer in the fall and after draining in the spring as the temperature increases. It is

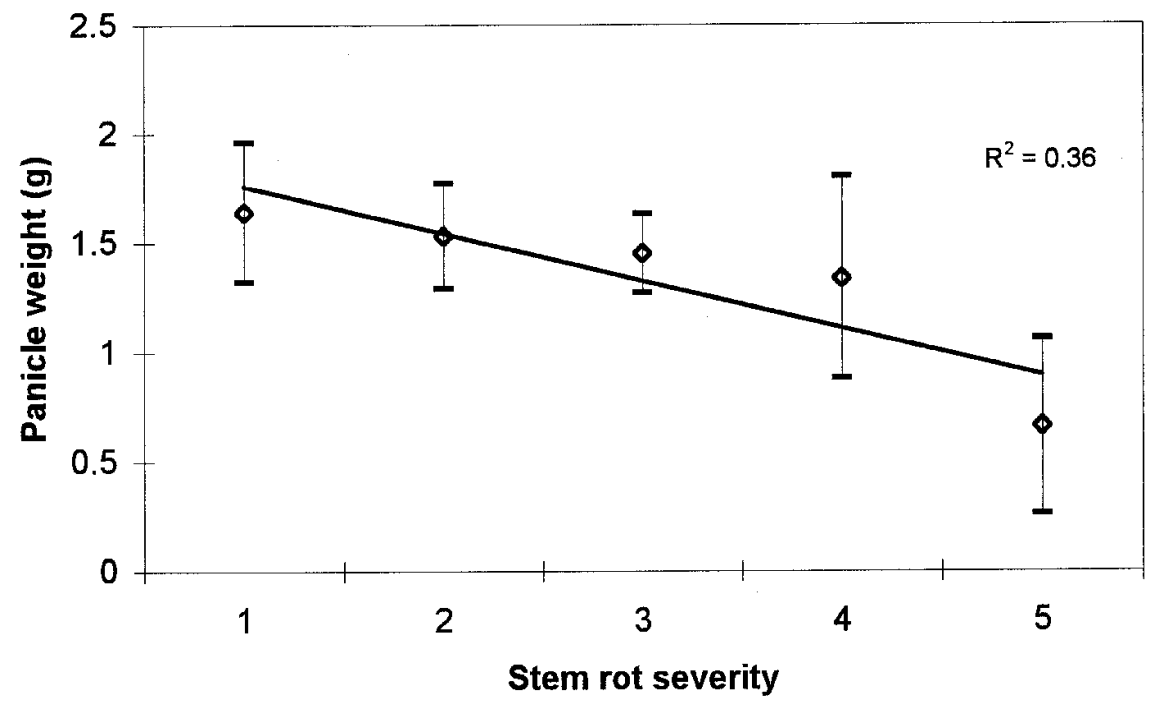

Fig. 2. Increased stem rot severity results in decreased panicle weight. Panicles were collected within each stem rot severity class $(1=$ healthy to $5=$ severe infection $)$ in 1997 from the Colusa County site. Panicles were collected from over 10,000 rated tillers. At each point, the bars represent the standard deviation. also possible that sclerotial decomposition was encouraged by the microflora populations in the winter-flooded treatments. Cartwright found differences in fungal microflora on stem rot sclerotia between different rice residue management systems (5). Such microflora differences, which were both fungal and bacterial, may explain some of the differences in sclerotial viability observed. Also, the flooding of stubble in November may have diminished the carbon availability in the residue for further sclerotial production.

Shahajahan found significant positive correlation between $S$. oryzae inoculum and stem rot severity (23). Yet, Webster et al. reported that, when inoculum levels exceeded 0.6 viable sclerotia per gram of soil, the linear correlation between inoculum and disease severity was lost (28). This conclusion supports our results that straw management subplots most often showed no significant differences in disease incidence and severity despite significant differences in inoculum levels. In almost all soil samples from the trial, levels of viable sclerotia per gram of soil recovered exceeded 0.6.

The lack of significant difference in yield as a result of disease occurring from high inoculum levels ( $>0.6$ viable sclerotia/g of soil) in some of the straw management treatments may be explained by the relationship observed between disease severity and panicle weight (7). Panicle weight was known to decrease with increased stem rot severity $(7,28)$, and this was verified in the present study (Fig. 2). If particular plots showed final disease severities of 2 and 4, we would have expected yield differences between these plots. Yet, most of the disease severity ratings averaged about 3 , without much variability. Inoculum in all treatments was almost always greater than 0.6 ; therefore, the disease severity ratings and yield reductions due to disease would not be expected to vary significantly between treatments. Admittedly, in this study, the relationship examined between disease severity and panicle weight lost its linearity as severity approached 5 (Fig. 2). This figure may bring to question the accuracy of the rating system; a more extensive rating system may have given a more precise description of the relationship of yield to disease severity. However, the trend that the figure

Table 3. Correlation coefficients for stem rot severity and yield

\begin{tabular}{lc}
\hline Year & Severity versus yield $^{\mathbf{a}}$ \\
\hline 1994 & -0.33 \\
1995 & $-0.80^{* *}$ \\
1996 & $-0.60^{* *}$ \\
1997 & 0.05 \\
\hline
\end{tabular}

a Stem rot severity is based on a scale of 1 to 5 , where $1=$ healthy and $5=$ severely infected. Yield is measured at $14 \%$ moisture; $* *=F$ is significant at $P=0.01$. 
suggests is also supported by the correlation analyses between harvested yield and severity (Table 3 ). The trend was observed in the 1994 data, then the trend continued significantly over the next two seasons.

Past reports show that, as nitrogen fertilization is increased, stem rot severity also increases (11). Past reports also show that, once the amount of nitrogen fertilizer applied provides for maximum yield response, no further increase in yield was obtained with further increases in nitrogen (25). On the other hand, it has been generally observed that stem rot severity is favored by nitrogen fertilization above that required for maximum yield response $(11,18,23)$. Preliminary results of other studies at the experimental site have shown that native nitrogen levels have increased in the subplots where residue has been incorporated due to mineralization of the straw incorporated. All plots received the same fertilization rate throughout the study; therefore, the incorporated plots contain higher nitrogen levels available to the plants than those where straw and stubble are burned or removed. Thus, disease severity could be higher in these plots due to nitrogen effects and an abundance of inoculum. In either event, it appears that disease severity in most of the plots is occurring at a level typical for this disease under inoculum levels and cultural factors that are occurring in the different treatments.

Each year, each 1.9-acre subplot was harvested in its entirety, except in 1997, when only a section through the center of each plot was harvested, resulting in higher and more uniform yields between treatments. This method of harvest did not take into account the effects of levees separating the treatments that can often have an impact on yield, particularly in 1.9-acre plots. Other exceptions likely contributing to the higher and more uniform yields in 1997 were a more aggressive use of herbicides due to the buildup of weeds in incorporated and rolled subplots. Also, rice blast disease was found for the first time in California in 1996. Because of the large investment in time and expense in the continuous-year trial, two applications of Quadris fungicide were applied during the 1997 season to reduce the potential impact of rice blast on the outcome of the study. The disease severity and yield data (Table 1) for the 1997 season suggest the fungicide applications contributed to lower stem rot severity during the 1997 season. This could have been expected because Quadris is also considered effective in controlling stem rot as well as aggregate sheath spot of rice, which occurs at a low level at the experimental site. Similarly, the lack of correlation between severity and yield in 1997 (Table 3) may be due to reduced variability of these factors, a result of the Quadris applications.
In conclusion, fall incorporation of residue followed by winter flooding appears to be the best alternative to rice straw burning for disposal of residue and management of stem rot. However, the cost of fall incorporation and the water for flooding is significantly higher than that of open field burning. Baling and removal of straw addresses the residue disposal problem in the field. However, the cost is significant and the alternative uses for the straw have been slow in development and do not yet offset the baling and removal costs. In addition, when straw is removed, potassium becomes deficient on some California soils after 3 years (R. Mutters, personal communication).

Although this study answered some important questions concerning the effect of potential cultural control methods for stem rot of rice, these trials also bring about new questions worthy of further study, such as: by what mechanism does winter flooding reduce overwintering sclerotia of $S$. oryzae?

\section{ACKNOWLEDGMENTS}

We thank S. Scardaci for his oversight of the field trial management for the first 5 years.

\section{LITERATURE CITED}

1. Bockus, W. W., and Webster, R. K. 1979. Decline in numbers and inoculum potential of Sclerotium oryzae in field soil. Phytopathology 69:389-392.

2. Bockus, W. W., Webster, R. K., Wick, C. M., and Jackson, L. F. 1979. Rice residue disposal influences overwintering inoculum level of Sclerotium oryzae and stem rot severity. Phytopathology 69:862-865.

3. California State Legislature. 1991. AB 1378-The Rice Straw Burning Reduction Act of 1991.

4. California State Legislature. 1997. SB 318Air Pollution: Rice Straw Burning.

5. Cartwright, R. D. 1992. Biodecomposition of rice residue and biocontrol of Sclerotium oryzae in California. Ph.D. diss. University of California, Davis.

6. Cintas, N. A. 1998. Effects of different rice residue treatments on Sclerotium oryzae. (Abstr.) Phytopathology 88:S106.

7. Cintas, N. A. 1998. Relationship of Sclerotium oryzae inoculum levels, stem rot incidence and severity, yield of rice in California, and bacterial populations recovered from $S$. oryzae sclerotia and rice stems under different rice residue management practices. Ph.D. diss. University of California, Davis.

8. Cooperative Extension University of California, Division of Agriculture and Natural Resources Publication 21498. 1992. Rice Production in California. Oakland, CA.

9. Harradine, F. F. 1948. Soils of Colusa County. University of California, College of Agriculture, Agricultural Experiment Station, Berkeley, CA.

10. Hussain, S., and Ghaffar, A. 1993. Effect of tillage practices on the population and viability of sclerotia of Sclerotium oryzae and yield of rice. Pak. J. Bot. 25(2):232-234.

11. Keim, R., and Webster, R. K. 1974. Nitrogen fertilization and severity of stem rot of rice. Phytopathology 64:178-183.

12. Keim, R., and Webster, R. K. 1974. Effect of soil moisture and temperature on viability of sclerotia of Sclerotium oryzae. Phytopathology 64:1499-1502.

13. Krause, R. A., and Webster, R. K. 1972. The morphology, taxonomy, and sexuality of the rice stem rot fungus, Magnaporthe salvinii (Leptosphaeria salvinii). Mycologia 64:103115.

14. Krause, R. A., and Webster, R. K. 1972. Sclerotial production, viability determination and quantitative recovery of Sclerotium oryzae from soil. Mycologia 64 (6):1333-1337.

15. Krause, R. A., and Webster, R. K. 1973. Stem rot of rice in California. Phytopathology 63:518-523.

16. Mikkelson, D. S., and Broadbent, F. E. 1981. Rice straw disposal by soil incorporation. Pages 46-54 in: Agricultural Residue Management-A Focus on Rice Straw. J. E Hill, ed. University of California, Davis.

17. Oster, J. J. 1992. Reaction of a resistant breeding line and susceptible California rice cultivars to Sclerotium oryzae. Plant Dis. 76:740-744.

18. Ou, S. H. 1972. Rice Diseases. Commonwealth Mycological Institute. Kew, Surrey, England.

19. Pal, D., and Broadbent, F. E. 1975. Influence of moisture on rice straw decomposition in soils. Soil Sci. Soc. Am. Proc. 39:59-63.

20. Pal, D., Broadbent, F. E., and Mikkelsen, D. S. 1975. Influence of temperature on the kinetics of rice straw decomposition in soils. Soil Sci. 120:442-449.

21. Sain, P., and Broadbent, F. E. 1975. Moisture absorption, mold growth, and decomposition of rice straw at different relative humidities. Agron. J. 67:759-762.

22. Sain, P., and Broadbent, F. E. 1977. Decomposition of rice straw in soils as affected by some management factors. J. Environ. Qual. 6:96-100.

23. Shahajahan, A. K. M. 1977. Etiology, epidemiology, and control of diseases caused by sclerotial fungi in Louisiana rice. Ph.D. diss. Louisiana State University, Baton Rouge.

24. Sharma, S. K., and Mehrota, R. S. 1986. Survival of rice stem rot pathogen in soil. Geobios $13(2 / 3)$ :97-99.

25. University of California and United States Department of Agriculture. 1993. Annual report-comprehensive rice research.

26. University of California and United States Department of Agriculture. 1994. Annual report-comprehensive rice research.

27. Webster, R. K. 1974. Relationship between inoculum level, disease severity and yield reduction in stem rot of rice. (Abstr.) Proc. Am Phytopathol. Soc. 1:106-107.

28. Webster, R. K. 1978. Measuring losses due to stem rot of rice. Proc. 17th Rice Tech. Working Group, College Station, TX

29. Webster, R. K. 1981. Influence of various methods of rice residue management on severity of stem rot disease. Pages 19-29 in: Agricultural Residue Management-A Focus on Rice Straw. J. E Hill, ed. University of California, Davis.

30. Webster, R. K., Bolstad, J., Wick, C. M., and Hall, D. H. 1976. Vertical distribution and survival of Sclerotium oryzae under various tillage methods. Phytopathology 66:97-101.

31. Webster, R. K., Hall, D. H., Wick, C. M., and Krause, R. A. 1971. Distribution and occurrence of Sclerotium oryzae on rice in California. Plant Dis. Rep. 55(9):757-759.

32. Webster, R. K., Wick, C. M., Brandon, D. M., Hall, D. H., and Bolstad, J. 1981. Epidemiology of stem rot disease of rice: effects of burning vs. soil incorporation of rice residue. Hilgardia 49(3):1-12. 